\title{
Wellbeing and support
}

Mental health of women in crisis' proclaimed a front-page headline last month. ${ }^{1}$ It appears that a survey carried out by Platform 51 of more than 2000 girls and women reveals that around two-thirds have mild to moderate mental health problems. $^{2}$ The report demands 'more appropriate support', notably counselling and psychotherapy, and, inevitably, more training for GPs, so that they can play a full part in the inflation of mental illness and the medicalisation of unhappiness.

Platform 51 was, until last December, known as the Young Women's Christian Association; an organisation forged in the heat of 19th century evangelical Protestantism has been born again in the spirit of new age feminist psychotherapy. ${ }^{3}$ The Platform 51 report was based on a poll commissioned from a market research consultancy and on focus groups and surveys of women using YWCA services over a 12-month period. It provides a good example of advocacy research, providing data to support a policy decided in advance; propaganda rather than science.

Three principles govern advocacy research. First, expand the definition of the problem. Second, discover that the scale of the problem is even greater than suggested by previous studies. Third, confirm a demand for the service provided by the organisation commissioning the research.

Platform 51 believes that the official definition of 'common mental health disorders' is too narrow, because it 'does not adequately capture the range of feelings and symptoms' presented by women, including issues of 'low selfesteem and self-confidence and stress'. Hence it favours a wider category of 'mild to moderate mental health problems'. Once virtually any adverse life experience is redefined as a 'trigger' provoking mental health problems, there is no limit on the scope for diagnosing mental illness.

While earlier studies have revealed mental illness at rates of 'one in six', Platform 51's 'research' shows that a shocking $63 \%$ of girls and women experience mental health problems. Extrapolating from their sample to the population of England and Wales, the
Platform 51 statisticians calculate that the lives of 15.2 million women are being blighted. The authors acknowledge that the problems revealed by their report are 'not new', but they claim that 'until we undertook this research we were unaware of just how bad things are'. They further claim that 'problems are getting worse', but produce no evidence for this.

It must be very reassuring for Platform 51 to discover that there is overwhelming approval for the provision of 'womenonly' support and counselling services of the sort that Platform 51 provides.

The title of the Platform 51 report brings together two of the key weasel words of the therapeutic society: 'wellbeing' and 'support'. The concepts of 'good mental health' and 'wellbeing' promoted by the Department of Health and the WHO trivialise the notion of a 'good life' by reducing it to psychological and physiological states and imply a government-ordained condition of personal and social harmony as the goal of human existence. ${ }^{4,5}$ If wellbeing is established as the purpose of life, it is not surprising that two-thirds of the population experience the vicissitudes of life as mental illness - and seek professional intervention to 'keep them from falling or sinking'.

\section{REFERENCES}

1. Hill A. Mental health of women in crisis. The Guardian 2011; 11 Jan:

http://www.guardian.co.uk/society/2011/jan/11/m ental-health-women-crisis (accessed 17 Jan 2011).

2. Platform 51, girls and women at heart. Supporting wellbeing in girls and women. January, 2011. http://www.platform51.org/resources/Supporting _wellbeing_in_girls_and_women (accessed 17 Jan 2011).

3. Doughty S. YWCA drops the word Christian from its historic name to call itself Platform 51. Daily Mail 2011; 7 Jan:

http://www.dailymail.co.uk/news/article1344779/YWCA-drops-word-Christian-historicPlatform-51.html (accessed 17 Jan 2011).

4. Department of Health. Confident communities, brighter futures. A framework for developing wellbeing, 2010.

http://www.nmhdu.org.uk/silo/files/confidentcommunities-brighter-futures.pdf (accessed 17 Jan 2011).

5. WHO. Media Centre. Mental health: strengthening our response. Factsheet number 220, Sept 2010. http://www.who.int/mediacentre/factsheets/fs220/ en/ (accessed 17 Jan 2011).

DOI: 10.3399/bjgp11X556399 